\title{
Salmonella Serotype Group A
}

National Cancer Institute

\section{Source}

National Cancer Institute. Salmonella Serotype Group A. NCI Thesaurus. Code C124379.

Characterization of salmonella bacteria subspecies as serotype group A based on the specific immunologic reactivity of cell surface lipopolysaccharide-protein chains called $O$ antigens. 